Informasi - ISSN (p) 0126-0650; ISSN (e) 2502-3837

Vol. 49, No. 2 (2019), pp. 77-9o. doi: http://doi.org/10.21831/informasi.v49i2. 27815

\title{
AQUA ADS AS AN INSTRUMENT OF INDONESIA NATIONAL IDENTITY DEVELOPMENT
}

\author{
Asnurul Novia Narendra \\ annarendra@student.uns.ac.id \\ Sri Kusuma Habsari \\ skhabsari@staff.uns.ac.id \\ Deny Tri Ardianto \\ denytri@staff.uns.ac.id \\ Program Studi Magister Kajian Budaya \\ Universitas Sebelas Maret Surakarta, Indonesia
}

\begin{abstract}
Advertising is not only present as a media that is able to introduce products of goods and service to encourage people to consume based on their needs, but rather to simulate life models and create fake needs made by producers. The research focused on analyzing the signs found on 6ooml Aqua mineral water bottle labels with themed Temukan Indonesiamu. The study aims to find implicit purpose of using themed labels Temukan Indonesiamu in a $600 \mathrm{ml}$ size Aqua mineral water bottle through the signs that appear on the ads. The study uses Rolland Barthes's semiotics method to five motions advertisements namely friendly, polite, mutual cooperation, sharing, and kindship advertisement to find the meaning of denotation - connotations contained in the advertisement so as to produce myths or implicit goals from the production of the advertisement themed Temukan Indonesiamu. The result showed that changes of Aqua packaging using themed labels Temukan Indonesiamu with the theme of polite (santun), friendly (ramah), cooperation (gotong royong), sharing (berbagi) and kinship (kekeluargaan) not only as a Nation's talent search program and a media representation of identity and culture of Indonesia, but encouragement of Aqua mineral water producers to consumers to buy Aqua mineral water not only based on the need of mineral water, but also based on simulations and false need created by advertisement, namely love for the Indonesia Nation as reflected in the $600 m l$ Aqua bottle label. The author's creation of the theme Aqua bottle was also seen by the author as a diversion of public attention by Aqua mineral water producers to the increasingly uncontrolled problem of plastic waste in Indonesia and the way to maintain the existence of products from Aqua mineral water producers.
\end{abstract}


Iklan tidak hanya hadir sebagai media yang mampu memperkenalkan produk atau barang dan jasa untuk mendorong masyarakat berkonsumsi berdasarkan kebutuhan dirinya, melainkan menjadi simulasi model kehidupan dan menciptakan kebutuhan palsu yang dibuat oleh produser. Penelitian berfokus kepada penganalisisan tandatanda yang terdapat pada label botol air mineral Aqua ukuran 6ooml bertema Temukan Indonesiamu. Penelitian bertujuan menemukan tujuan implisit digunakannya label bertema Temukan Indonesiamu pada botol air mineral Aqua ukuran 6ooml melalui tanda-tanda yang muncul pada iklan. Penelitian menggunakan metode semiotika Rolland Barthes kepada kelima iklan gambar bergerakyaitu iklan versi ramah, santun, gotong royong, berbagi, dan kekeluargaan untuk menemukan makna denotasi konotasi yang terkandung pada iklan sehingga menghasilkan mitos atau tujuan implisit dari diproduksinya iklan bertema Temukan Indonesiamu. Hasil penelitian menunjukan bahwa perubahan kemasan Aqua dengan menggunakan label bertema Temukan Indonesiamu bertema Santun, Ramah, Gotong Royong, Berbagi, dan Kekeluargaan tidak hanya sebagai program pencarian bakat anak Bangsa dan media representasi jati diri dan kebudayaan Indonesia, melainkan dorongan produsen air mineral Aqua kepada konsumen untuk membeli air mineral Aqua tidak hanya berdasarkan kebutuhan akan air mineralnya, namun juga berdasarkan simulasi dan kebutuhan palsu yang diciptakan oleh iklan yaitu rasa cinta kepada Bangsa Indonesia yang tercermin pada gambar label botol Aqua ukuran 6ooml. Penciptaan botol Aqua bertema Temukan Indonesiamu juga dilihat penulis sebagai pengalihan perhatian masyarakat oleh produser air mineral Aqua terhadap semakin tidak terkendalinya persoalan sampah plastik di Indonesia dan cara mempertahankan eksistensi produk dari produser air mineral Aqua.

Keywords: Aqua Ads, Semiotics, Representation

\section{INTRODUCTION}

Almost all people know about advertising and its function. According to the Indonesian Dictionary, advertising is a medium that functions to notify or introduce products or results to the public (KBI, 2008: 572 ). Slightly different from KBI, Jefkins (1997) defines advertising as a media product that is used as a persuasion tool to buy or consume the goods offered (Jefkins, 1997). In a broader sense, Kasali (1995) defines advertising as part of the product marketing process that focuses on the community through a tool called the media (Kasali, 1995). These three definitions make advertising interpreted as a medium for channeling information from ad producers to ad readers for marketing purposes, invitations and even encouragement to consume the products or services offered.

As a message distribution tool that is able to introduce brands, products, and companies that support it (Yuniyanto \& Sirine, 2018: 22), advertisements contain influential marketing strategies to stimulate, influence, and encourage buyers to buy products and consume them ( Elisa \& Firdaus, 2015: 299; Poluan, Lumintang \& Untu, 2016: 671), thus increasing the company's sales volume (Juliyanti \& Zuhdi, 2012: 1).

In addition to functioning as a driver of consumption practices, advertising is believed to be able to provide a change in attitude or behavior to the reader through the messages contained therein. It is because advertising distributes ideas from producers to the reader which then influences the thoughts, perceptions, and behavior of the reader (Fiske, 1990: 11; Morissan, 2010: 17). It makes people will imitate to do or consume something based on the exposure provided by the ad. 
Types of advertisements that function as a medium of information as well as community reminders are more often referred to as public service advertisements. Public Service Advertising is one type of advertising created with social or socioeconomic objectives, especially on improving the welfare of the community (Nuradi, 1996: 136). Public service advertisements are one of the promotional strategies used in social marketing activities (Nisa, 2015: 158). Public service advertisement is intended to be present to the community and change the behavior of the community according to the wishes of social marketers (Lukitaningsih, 2013: 117; Nisa, 2015: 158).

Public service advertisement give rise to two types of advertising audiences. The first audience is the active community that is able to negotiate the meaning of advertising, on the contrary, the passive audience is the community that sees advertisements as impressions without being able and willing to read the meaning of advertisements that are served (Akalili, 2018: 182). The success and effectiveness of public service advertisement pivots to the creative processing of social messages that are served (Atika \& Chandrabuwono, 2018: 257). In public service advertisements, advertisements can be used as a means of cultivating understanding, especially in children. That is why many public advertisements use child characters to facilitate the introduction or giving of norm values to the community from an early age (Nursalim, 2014: 255).

\section{Advertising as a Media Representation}

Advertising does not only exist to encourage and shape society based on exposure exemplified by advertising. But advertising also serves as a medium of reflection of people's lives or what is called a mirror of society. Advertising acts as a mirror of the reality that occurs in society (Kusumastutie \& Faturochman, 2004: 130). Advertising describes how the shape of society and the values and norms adopted therein. It is very unlikely that advertisements will be rejected or ignored by the community because advertising also arises from the needs of the community itself (Adorno \& Horkheimer, 2006: 42).

The image or representation presented by advertising is not always be seen as a truth. Because the world which is the object of representation is not something that is absolutely what it is, but rather the result of how it is understood and viewed through a point of view (Cavallaro, 2004: 72 ). Instead representation is often used as a tool to legitimize the ideology conveyed in order to discipline the subjects of adherents (Cavallaro, 2004: 73). So that people will follow the life model exemplified in the ad.

This phenomenon is referred to as nonvalue-free advertising. Advertising forms a system that will influence people's lives in order to achieve a predetermined condition (Adorno \& Horkheimer, 2006: 41). The form of the system becomes the axis of life style that makes people obey the prevailing hierarchy (Adorno \& Horkheiner, 2006:48). The hierarchy certainly lives as a "guide" and takes the form of norms or values that become the rules in the community (Hadadi \& Almsafir, 2014: 274).

\section{About Aqua Ads - Temukan Indonesiamu}

Aqua is one of the bottled drinking water brands (AMDK) reached by Danone Group and developed in Indonesia under the auspices of PT Aqua Golden Mississippi Tbk since 1973. As one of the brands of AMDK, Aqua works closely with the Ministry of Health of the Republic of Indonesia to provide healthy hydration for the people of Indonesia (AQUA, 2011). This encourages Aqua to continue to maintain the quality of its products and promote the movement of healthy Indonesian concern through hydration and healthy drinking water.

Temukan Indonesiamu is one of the programs created by Aqua as a manifestation of Aqua's exception in the preservation of the values of Indonesian art and culture (AQUA, 2013). This program is intended for young Indonesians to explore Indonesia's wealth through digital technology and at the same time express their love for art, 
especially photography and graphic design. As a result of the program, Aqua 6ooml size bottles has changed. The 6ooml Aqua bottle which was originally only wrapped with the main logo design from the Aqua producer in the form of a mountain image, is now filled with Indonesian themed designs, especially culture, art, and Indonesian characteristics.

In this advertising product, Aqua combines the concept of sales and Public Service Adverts wrapped into one. Public Service Advertising, which is defined as a type of advertisement created with the aim of improving social and economic conditions that focus on improving the welfare of the community, is used by Aqua producers as an instrument of planting or raising awareness of the value of Indonesian culture to the community.

In the theme of Temukan Indonesiamu, Aqua has five types of labels. Namely Friendly (Ramah), Courteous (Santun), Mutual Cooperation (Gotong Royong), Sharing (Berbagi), and Kinship (Kekeluargaan). These five labels are used by the writer as the object of research to see the representation of the identity of the Indonesian Nation through the results of art and culture built by Aqua advertising.

\section{LITERATURE REVIEW}

\section{Advertisement as a Medium for Drive Public Consumption}

Advertising is able to encourage people to consume and decide on the choice of products offered. This is evident in the environmental conditions that show that people are more interested in using online shopping applications that offer security in shopping that comes from advertisements served compared to the large selection of goods and low price offers from the conventional market that comes without advertising (Asih, 2016: xi).

However, advertising is proven unable to stand alone in increasing public awareness of a product brand, but requires supporting factors such as slogans and/or jingles (Dewi \& Sugandi, 2019: 141). This review's literature encourages the existence of this research to prove the possibility of finding your Indonesia as a slogan or jingle with the theme of loving the Indonesian people which will raise public awareness to love the products of the nation itself.

\section{Advertisement as Mental Control and Psychology of Community}

Advertising is very influential on the mental development of society (Prasasti, 2017: 2). Mental development of society is formed based on the impressions that exist in advertising. This happens because advertising plays a very active role in guiding society in acting and deciding something (Nurita, 2016). Like it encourages buying something and produces certain effects when people are able or unable to consume the goods advertised.

Advertising is also not only used as a commercial medium in introducing a product or goods and services, but also acts as a media providing information to social control (Suryono \& Astuti, 2013: 19). Advertising is able to influence the cognition, affection, and social behavior of its people (Virga, 2014: 17), because each ad has a connotative meaning for the development of a myth which is the purpose of the advertisement (Suryono, Astuti, Rahayu, Widayati, \& Hariyanto, 2019: 46). However, advertisements bring different effects on each reader. The influence appears in the form of different interactions between consumers (Fikri, 2018: 46).

\section{Advertisement as a Representation of the Community}

Advertising is a medium that functions as a representation or reflection of the condition of society (Rahayu \& Afrianto, 2017: 106). The representation or reflection is present from the formula contained in the advertisement as a rule which is used as a standard for disciplining people's lives (Fauzi, 2018: 15). In other words, advertising becomes a discourse-building media that will later be used as a standard tool for public discipline.

From the overall literature review 
that has been found, the author decides to complete the research cluster that has not been done specifically by using Aqua mineral water advertisements with the theme Temukan Indonesiamu. The study was aimed at finding the implicit purpose of Aqua mineral water producers in displaying a 6ooml Aqua ad with the theme of Temukan Indonesiamu by analyzing the signs contained in advertisements based on the Rolland Barthes semiotic method which focuses on the meaning of denotation, connotation and myth.

\section{METHODS}

Theories and methods of Semiotics the authors use as a means of dissecting the signs used by Aqua ad producers in distributing ideologies and thoughts implicitly through the theme of Temukan Indonesiamu.

Semiology (semiotics) is a science used in looking at sign systems in the form of pictures, gestures, musical sounds, objects, and other types of signs that are incorporated in an association (Barthes, 1964: 9). Semiology has four types of element pairs produced through linguistic structures, namely Language and Speech, Signified and Signifier, Syntagm and System, and Denotation and Connotation (Barthes, 1964: 12). These four systems are used as a method of searching for the meaning of signs as the nature of semiotics itself.

Barthes believes that the connotations are interpreted as a combination, where the denotation shows signs with a literal meaning (actually) agreed by together or in the form of an original reality that is explicit, direct, and certain (Sobur, 2009: 8), while the connotation with meaning figuratively and openly to various interpretations (Sobur, 2009: 8).

In Rolland Barthes's semiotics, analysis is divided into two stages. First stage is done to get denotation of signifier and signified sign. Whereas, the second stage is done to get connotation of signifier and signified sign and produce myths.

The author uses the Rolland Barthes semiotic method which is divided into three stages. The first stage is done to describe the denotation meaning of the five advertisements as research objects. This stage describes the literal meaning or the concrete meaning (the real meaning or seen directly), and what it is in advertising. The second stage is to describe the meaning of connotation. At this stage, the figurative meaning is search for the meaning of the signs used in advertising. The signs used can be in the form of colors, shapes, or objects that are used by Indonesian people in their daily lives. The last stage is the stage of searching for the meaning of myth. The meaning of myth is derived from the withdrawal of meaning in the second stage to be combined with the values or norms prevailing in Indonesian society such as the culture of Indonesian society.

From these three stages, the study found a correlation between the use of the Temukan Indonesiamu theme with signs used in Aqua mineral water advertisements.

The author only focuses on research to find the meaning of the denotations connotation of the label Aqua "Temukan Indonesiamu" version of "Friendly, Courteous, Sharing, Mutual Cooperation, and Kinship". The object of the study is the author obtained at the link https://youtu.be/ t5oEGtPYKIA with a duration of 23 seconds.

\section{RESULT AND DISCUSSION}

The author finds that making Aqua packaging specifically for Temukan Indonesiamu is not only intended to create variations of packaging, but to build a discourse of self-identity that Aqua is very concerned and integrated with Indonesia. With this theme, the producers intentionally created the need for "Love Nation" through Temukan Indonesiamu to encourage consumers to prefer the product over other bottled water products.

\section{Aqua Label Analysis Polite (Santun)}

The Aqua label Polite, in bahasa is Santun, is one of the five images used on the Aqua Temukan Indonesiamu label. It can be seen that the Aqua Label image politely describes the number of pairs of people who 
are shaking hands. The courtesy label image is filled with a combination of blue and white.

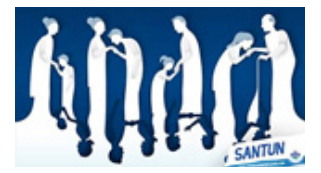

Figure 1. Aqua Label Polite version Source: Aqua Ads Temukan Indonesiamu oo.o9

\section{Denotation Meaning}

The polite version of the Aqua Label is depicted with four pairs of people who are shaking hands. In denotation, handshaking is defined as a greeting activity, greeting by shaking hands (KBI, 2008: 1346).

The first couple is a mother who shakes hands with a boy. The author sees the first couple as a mother through the hair rolls or bun contained in the picture. Male body size smaller and shorter than a female character makes the writer describe it as a boy. The second pair is described by the writer as a mother who shakes hands with a teenage boy. The author calls it a teenage boy because it has a higher body than boys in the first couple. The first pair and the second pair interpreted the author as the same person. However, changes in body size are interpreted as body development and age.

The third pair of writers describe as a daughter who shakes hands with a father. While the fourth pair of writers describe as a teenage girl shaking hands with a grandfather. The description of the teenage woman the writer gets from a higher body shape than the picture of the girl in the third pair. While the description of the grandfather got from the stick figure. The third and fourth pictures in the form of a girl and a father are also interpreted as the same couple, but they get older. The girl in the third picture becomes the adult woman in the fourth picture, while the father turns into a grandfather.

\section{Connotation Meaning}

Courtesy is defined as mutual respect, especially between the younger generation and previous generations. Men or women, Indonesian people always apply polite rules to anyone. The concept of courtesy owned by Indonesia is also interpreted as young people respecting parents, and parents respecting and protecting young people.

Courtesy is done by shaking hands. In Indonesia, shaking hands is interpreted as connotation as a sign of giving honor or respect. In addition, giving greetings by shaking hands and bowing a little is a sign or identity of the Indonesia people. The concept of growth that occurs in thepicture is intended as a sign that the courtesy value owned by the people of Indonesia is a hereditary value that is still maintained today. While the hair roll or bun is interpreted by the writer as a sign of traditional Indonesian civilization or culture.

\section{Myth Meaning}

Signifiers and signified at the stage of denotation and connotation produce myths that show that Aqua is present in the lives of Indonesian people since ancient times until now. Aqua is present by embracing both the entire Indonesian community regardless of age and gender. By providing Aqua anywhere and anytime so that it can be easily consumed by the people of Indonesia.

The white color used as the dominant color in polite images is symbols that polite is a pure, clean attitude, and show the advertising itself. Like Aqua's presence to the Indonesian people which is based on a sense of sincerity to share. In addition, the white color also gives the impression of Aqua in the form of safe, pure, clean and positive nature (Basuki, 2017), which will be able to give an impact to its consumers a kindness, purity, purity, and perfection

The white color is also used as a symbol of the Aqua brand symbol which is dominated by blue and white. The use of white color by the producers certainly cannot be separated from the creation of a clean, fresh, pure, healthy and positive impression on Aqua products which will be accepted by consumers when they see the picture. This is certainly a motivating factor for the public to be interested in consuming Aqua products because of the sense of comfort themselves in the advertisements that are served. Because 
the presentation of colors from producers to consumers will produce the emergence of special feelings through the effects of the colors themselves which will later produce positive or negative characteristics of the products offered

\section{Aqua Label Analysis Polite - Horizontal}

Not only one side, polite image has two vertical sides that can be interpreted. If in the first picture which is dominated by white, the producers are trying to convey a message through a picture of some Indonesian people in dark-blue basic colors who shake each other. If reversed vertically, the image above will be shaped as follows:

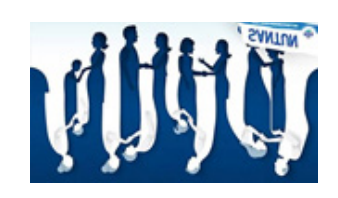

Figure 2. Aqua Label Polite version - Horizontal Source: Aqua Ads Temukan Indonesiamu 00.00.09

\section{Denotation Meaning}

Same as the polite image version 1, polite version 2 consists of four pairs of people who are shaking hands. The first pair consists of a boy shaking hands with an adult woman. This time the woman no longer had a bun, but had short hair on the shoulders. The next pair consists of men and women of almost the same age. This is evidenced by the shape of their hands that are parallel, not high and low like the shape of couples of different ages.

The third pair consisted of a pair of women who seemed to be of the same age and were young to each other. This is evidenced from the parallel hand shape and hair style they have (modern, not a bun). The next pair is the mother and daughter pair, where the mother embraces the child. In this couple, shaking hands is not only realized by shaking hands, but also hugging (embracing) from the old to the young.

\section{Connotation Meaning}

Through courtesy image version 2 , it can be seen that the concept of courtesy formed by the producer is polite who does not recognize age and gender. Producers illustrate that all humans can carry out the practice of modesty like the picture by shaking hands without having to recognize age, gender, or appendages such as treasure or throne.

The use of dark blue in the picture is intended as a builder of the impression of knowledge, strength, integrity, and seriousness. This is intended as a symbol of Aqua which will give effect to knowledge (mind fitness), strength and integrity for consumers who will later support their customers in carrying out various activities. Like the Aqua jingle in other editions that read "Butuh Aqua?" or which means drinking Aqua can restore the focus of mind and self that had lost. The blue color is also used by producers as the Aqua brand symbol consisting of white and dark blue which means purity of water from nature.

\section{Myth Meaning}

As said by John Fiske that advertising is not only a means of promotion of goods, advertising is also a vehicle of communication that the process is able to influence the behavior or the state of mind of other individuals (Fiske, 1990: 11). The picture is interpreted by the author as an ideological development by the producer of Aqua products that are very popular with the people of Indonesia (affordable prices). The use of various types of figures in the picture is intended as a sign that Aqua is a product that can be consumed by all Indonesian people in any circle (young and old, large - small, modern-traditional, and affordable prices).

\section{The Meaning of Aqua Label "Friendly"}

In the Indonesian Language Dictionary, friendly (ramah) is interpreted as kindhearted, attractive language, sweet speech and attitude towards others, sociable and fun in association (KBI, 2008). Through the Aqua label "Friendly", producers try to present symbols and other signs that can convey a friendly concept and also its relationship with the people of Indonesia and Aqua. 


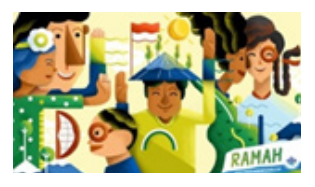

Figure 3. Aqua Label "Friendly" Version Source: Aqua Ads Temukan Indonesiamu 0o.00.07

\section{Denotation Meaning}

On the Friendly version of the Aqua label there are pictures of faces, smiling lips, several types of people with their hands pointing up, and some natural landscapes such as mountains, forests and rice fields. Producers also use images of the sun, red and white flags, as well as several wave lines that are made into hair.

\section{Connotation Meaning}

The smile lip signifier found in the six faces is seen by the author as a symbol of friendliness, joy, and happiness. This is supported by the shape of the lips curved downward (happy emojis) and not curved upward (sad emojis).

The friendly concept is also supported by a signifier picture of "greeting hands". The greeting hand is seen by the writer as a signifier of the impression "friendly", open, and accepting. All of them causing a myth in the minds of the authors that Aqua is an environmentally friendly product (natural, healthy).

Producers affix images of red and white flags as signifier from the State of Indonesia. The flag is presented as a symbol that the overall conditions contained in the picture are a reflection of the Indonesian people. At the same time emphasizing that Aqua is the ADMK produced by the Indonesian State.

Next signifiers are rice fields, mountains, sea, and also trees that are present as an index of the hydrological process, which is the creation of natural water. The author calls it an index that describes the causal relationship used as the process of creating Aqua water.

\section{Myth Meaning}

As one of the producers of bottled drinking water marketed in Indonesia, a country which rich in art and culture, the producer combines these signs as a description that Aqua is a very natural mineral water product, good for the body (supported by the use of peach yellow and the symbol of the sunrise), and is also marketed throughout Indonesia. With the presence of various human forms in the picture, it can be seen that Aqua is an AMDK that is able to be consumed by all Indonesian people without having to distinguish between races, or cultures at an affordable price.

This is what the writer called the development of self-identity by Aqua. Producers use the above signs not only to show the diversity of Indonesia, but also as an affirmation that Aqua is an AMDK that is not only present to obtain economic benefits, but also parties who care about Indonesia's natural products (mineral water) and the appearance of Indonesian people (culture).

\section{The Meaning of Aqua Label "Mutual cooperation"}

Mutual cooperation (Gotong Royong) is interpreted in the Indonesian Language Dictionary as a synomime of helping, and also struggling and working together, helping the weak and mutually reinforcing (KBI, 2008: 498).

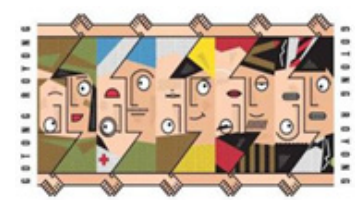

Figure 4. Aqua Label version of "Mutual Cooperation"

Source: Aqua Ads Temukan Indonesiamu 00.00.12

\section{Denotation Meaning}

On the Aqua label version of the mutual cooperation, the producer uses a picture of the faces of five pairs of people facing each other. The face is formed equally and distinguished by its color. It can also be seen that there is a picture of a hand held together by a picture of one person to another. 


\section{Connotation Meaning}

Mutual cooperation, which means helping each other symbolized by hands holding each other and clenching on both sides of the left and right as well as up and down. Although the depictions of faces, smiles, eye shapes, and also the clothes used in the picture above are almost different from each other, but the picture of the hands holding each other indicates that they are together to go to the goal they have, namely unity.

\section{Myth Meaning}

On the mythical side, the image of the concept of mutual cooperation combined with the diversity of the forms of Indonesian society is a symbol that Aqua is an AMDK that is not only present as a consumption product, but also a product that is able to unite the differences. Aqua can be consumed by anyone, regardless of age, occupation, position, beliefs, or the culture behind it. In addition, Aqua is also known as one of the bottled drinking water brands that has a role in helping Indonesians survive drought conditions, especially in certain areas. As in 2012, Aqua helped villages experiencing drought in Pasuruan (Yakub, 2012), in Cianjur, West Java in 2014 (Yopi, 2014), two villages in West Nusa Tenggara in 2016 (Lahitani, 2016), and recently on Gunung Kidul (Safutra, 2019). This side is what the writer called the development of Aqua's identity through the media.

The advertisement shows that Aqua contributesin maintaining theharmonyof the situation of Indonesian people as evidenced by the use of the Temukan Indonesiamu theme as an advertising concept. The concept of advertising is presented as a discourse that Aqua is one of the products that has high concern for Indonesia, culture and diversity as well as public health conditions. The concept of advertising is also intended as a discourse that by consuming Aqua, Indonesian people can unite to achieve shared goals with the attitude of mutual cooperation.

\section{The Meaning of Aqua Label "Sharing"}

In the Indonesian Dictionary, sharing (berbagi) is defined as breaking something into several parts and giving to other parties (KBI, 2008: 114). So that when converted to "sharing", these activities are carried out together (sharing and giving). Sharing is not limited only through goods, but also anything including smiles, health and happiness.

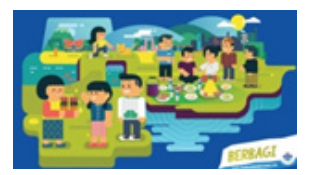

Figure 5. Label Aqua version of "Sharing" Source: Aqua Ads Temukan Indonesiamu 00.00.10

\section{Denotation Meaning}

On the sharing version of the Aqua label, the producer describes the state of sharing with a group of people who give something to others. Can be seen in the picture, the concept of sharing is marked by a picture of gifts, food, or a gathering of several people in an activity and location.

\section{Connotation Meaning}

Through this picture, Aqua tries to give an example to the community that sharing activities are fun activities and have a positive impact on the giver and the recipient. The smiling face formed in the picture above is present as proof that the activity is a fun activity.

Sharing is not only limited to fellow humans, but also animals. It is shown by dog signs. The presence of the animal symbol is used by producers as a representation that Aqua is not only concerned with the welfare of the people of Indonesia, but also the entire contents of the Indonesian State, including animals and plants. This is in accordance with the characteristics of Aqua water which is a purely natural product through the hydrological cycle.

Beautiful natural images, bright blue skies, green grass, and several water sources makeitclear that Aqua has agreatconcernand contribution in creating a state of harmony for Indonesia. In connotation, the picture 
above becomes a symbol of the hydrological cycle which is the source of Aqua products. This symbol is used as non-tangible evidence to the public if Aqua is truly a quality natural product. Although consumers do not see the Aqua production process directly.

The picture of the diversity of clothing types interpreted by the author as a batik style, various foods, to various forms of buildings that are used as background in the picture, are seen as symbols of Indonesia's diversity phenomenon. Aside from being a symbol of Indonesian products, these signs are also used as an explanation that Aqua products are available throughout Indonesia. The use of different body colors in figures is drawn to emphasize that Aqua is present for all people without distinguishing one another.

\section{Myth Meaning}

As one of the Semi-Public ServiceAds, the picture is a sign that Aqua is not only present with economic interests (product sales), but also a concern for the people of Indonesia by sharing health, joy, and happiness through the purity of Aqua mineral water. Aqua care is not only for humans, but also for all creatures that live in this world in the form of animals, plants and nature.

\section{The Meaning of Aqua Label "Kinship”}

Kinship (kekeluargaan) is interpreted in the Indonesian Language Dictionary as a condition and way related to the family. In the concept of the last advertisement carried by Aqua, the impression and the message of "kinship" is symbolized by the picture of the community who are mutually together and hand in hand in carrying out their life activities..

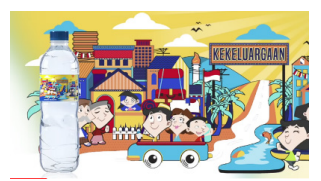

Figure 6. Aqua label "Family" version Source: Aqua Ads Temukan Indonesiamu 00.00.14

\section{Denotation Meaning}

The first sign found by the author on the Family version of the Aqua label is a happy face sign that is depicted on almost all the existing characters. Ad producers also use different markings of building colors, building types, dress colors, and diversity of transportation. Producers also use background in the form of mountains, trees, clouds and sun.

\section{Connotation Meaning}

The happy face sign that is depicted on almost all the characters proves that the state of kinship is a very pleasant and happy situation. Ad producers use different markings of building colors, types of buildings, colors of clothes worn, to the types of transportation used as symbols that Indonesia is full of differences. However, these differences actually make Indonesia more beautiful and richer in culture by embracing and assuming that all Indonesian people are family. The producer put pictures of clouds, mountains, and also water sources (ponds) as a symbol of the hydrological cycle which is the source of Aqua water produced.

\section{Myth Meaning}

On the Aqua side, the concept of kinship is intended as a sign that Aqua is a society that is spread throughout Indonesia and can be consumed by anyone, without knowing their gender, race, or status.

Affixing images of clouds, mountains, and water sources (ponds) are as a symbol of the hydrological cycle with the aim of hegemony the community that Aqua is a product produced by nature, even though they have never witnessed the process of making Aqua water.

From the sign of kinship made by the producer shows that Aqua is present not only as an advertisement aimed at promoting products and getting profits, but also as a Community Service Adverts which tries to remind some of the noble qualities of the Indonesian nation, one of which is kinship, to fill independence. This independent condition certainly comes from the symbol of the red and white flag that is served. 


\section{The Meaning of Finding Your Indonesia}

From the whole picture contained in the Aqua advertisement, the writer gets several points of relationship between Indonesia, Aqua, the theme, and the ad that aired.

The first point is about the symbols used by the producer as a sign of "difference" which is owned by the State and the people of Indonesia. This symbol is also used as a confirmation of the theme carried by Aqua, Temukan Indonesiamu. Through differences in the shape and color of buildings, differences in clothing used by figures in the picture, different types of transportation, different types of food, different types and colors of skin, differences in shape and color of hair, lips, eyes and nose, differences in age, to differences in appearance the figures are traditional and modern.

From this first point, theauthorinterprets that Aqua exists alongside Indonesia's diversity by embracing and uniting. Aqua does not distinguish anyone from being a consumer. Everyone can buy and consume Aqua despite having a different background in life. Aqua can also be consumed in any weather climate and can be accompanied by any type of food in Indonesia. Aqua almost displays most types of buildings in Indonesia to say that Aqua is present everywhere and is very easy to find. So, unconsciously, Aqua tries to instill the value that Aqua is an AMDK that is very concerned with the natural conditions of Indonesia, Indonesia's diversity and also easily consumed because it is available everywhere. This diversity also shows that Aqua is a popular product at an affordable price (all people will be able to buy it).

Although it gives the impression that producers do not differentiate Indonesian culture from one another, Aqua uses themes and symbols in it as a "differentiator" itself with other bottled water products. By using colored and themed packaging, Aqua deliberately builds a self-symbol that will later becomea symbol approved by the community as well (The Temukan Indonesiamu label is Aqua's AMDK label). As a result, the people of Indonesia will become more familiar with Aqua as an Indonesian culturethemed AMDK. Because it is necessary for a producer to know the condition of the target community to be able to decide the sign or symbol used in advertising with the aim of succeeding in the form of the message delivered (Tinarbuko, 2009: 32). And Aqua has succeeded in building that symbol.

The second point is about Aqua ads which are not only present as commercial advertisements (product sales), but also Public Service Ads. As a Public Service Adverb that serves as a reminder, as an example, to a tool to change people's behavior, Aqua tries to come along with the basic characteristics possessed by the Indonesian Nation. Namely polite, friendly, sharing, mutual assistance, and kinship. The use of the theme was also reported by the writer as a revival of the character of the Indonesian nation which has been increasingly worrying (fading). Certainly, eroded by the current of globalization that makes Indonesian people increasingly liberal and forget culture. This is certainly in line with the function of the Public Service Adverts which is intended to raise public awareness of a number of problems or conditions that are not compatible (Tinarbuko, 2009: 36) which will bring up a solution.

In attracting the attention of consumers to buy and consume Aqua, producers need to foster an ideology that is in harmony with the characteristics of the Indonesian people, to make it easier for producers to introduce, distribute, and make Aqua acceptable to the public. As Apter said, the interests - values - choices are interrelated and overlapping (Apter, 1996: 236), especially in advertising. Ads that have an interest in marketing products and getting profits, deliberately bring positive value to the products offered.

In thiscase, Aquaaccompanied the theme of Temukan Indonesiamu as an instrument that would later bring up positive values by consumers who read the ad. Producers build the ideology that Aqua is not only present as a trading practice, but also a party that has great concern for the Indonesian people, both 
natural and possessed characteristics. As a result of developing this discourse, a choice arises. This choice will eventually encourage ad readers to prefer Aqua over other bottled water products because of the concept that is in line with Indonesian characteristics, namely "Care for Nature and the Indonesian Community" by the producers. This is what was meant by the author in the opening chapter that every advertisement present must bring a form of self. The form of selfpresented to the public is that Aqua cares about the people of Indonesia and their diversity. So Aqua brought up a special packaging label with the theme of Indonesian culture on the products being sold.

In the development of a positive identity and form of self, the author sees that the producer has taken a very telling way. Especially through the use of the theme Temukan Indonesiamu which is side by side with the cultural code, moral aspects and knowledge of Indonesia. This theme then becomes a supporter of advertising to be easily captured and accepted by the public (Tinarbuko, 2009: 42).

The next point is about the design used by the producer. If initially AMDK Aqua was only wrapped with a simple packaging with a picture of a mountain with a predominance of darkblueand white, the presence of Aqua with the design version of Temukan Indonesiamu is certainly a new color. Especially on this theme the producers deliberately separate one version from another. In other words, the five versions are not put together in one bottle. Distribution of products with different packaging is also not fully distributed. So that allows consumers to have difficulty finding all types of labels in the same store. This is what the author sees as a practice of driving consumerism by producers to advertising audiences. As a result, consumers must buy products again and again to be able to enjoy the image directly and overall.

Advertisements aimed at the audience in all circles would certainly cause great curiosity and curiosity about the packaging image directly. Moreover, the duration of the ad which is only 23 seconds makes the ad become a flash ad filled with color and images. Bright colors that are served on the ad certainly cause bright, cheerful, and fun effects. Again, this has encouraged the audience to be interested in knowing the details of the picture and buying Aqua because of the uniqueness of the bottle label. Tricks attracting the author found in these advertisements such as facial image, body language, visual representation, or images that start from the shape of a flat figure. The appearance of the face along with the expressions that the producer brings to the advert creates a lively effect on the image. So that the audience feels they are communicating live with advertisements (Danesi, 2004: 58-59), and cause interest in consuming products. Visual representation in the form of natural conditions, wave lines, to the body's expression of the figure in the picture as a complement also gives the impression of comfort for the audience (Danesi, 2004: 86-87). So that again - again cause positive feelings and encourage consumers to choose the product.

It is at this point that the writer refers to it as the falsity of the needs brought about by the practice of capitalism. If initially consumers only needed water to drink, now consumers will switch to the selection of drinking water because of the packaging they have (the practice of bottle label collection). So it is undeniable that the embodiment of the Aqua label version of Temukan Indonesiamu version is one of the ways used by producers to re-draw consumers' attention to Aqua products. This will be done by producers considering the increasingly rampant competition of bottled drinking water products.

Although the theme of Temukan Indonesiamu is used as an impression and symbol that Aqua is a product that cares about the environment, the authors see that this is merely a diversion of people's attention to the problem of community waste that occurs in Indonesia and precisely because of plastic waste. If people increasingly buy bottled drinking water especially those who use plastic as packaging material, it is certain that 
plastic waste in Indonesia will increasingly mount. With more and more plastic waste being produced, Indonesia's environmental damage is even greater. Supposedly, if Aqua really cares about the state of the Indonesian environment, producers will encourage the Indonesian people to minimize the use of plastic water bottles. In addition, the use of special labels should not be placed on small size Aqua that cannot hold much water and encourage people to buy again and again.

\section{CONCLUSION}

Through the theme of Temukan Indonesiamu, Aqua adverts transforms itself into a semi-Public Service Adverts and builds an identity that Aqua cares about nature, culture, and the people of Indonesia. Through the theme of Temukan Indonesiamu, Aqua ad producers create a false need for consumers of bottled water, that is the consumption of art or the practice of Aqua bottle collection of Temukan Indonesiamu versions. Making a special label on Aqua becomes a practice of capitalism that is not realized by consumers and the lure of the appearance of false needs. Because of the fact, consuming Aqua in 6ooml bottle continuously will actually damage nature because of the increasing plastic waste that Indonesia has. Based on these findings, the implication is that public service advertisements continue to be a driving force for consumption that will benefit ad producers. Further research can be done using other public service ads or Aqua ads with different themes to fill in the gaps of existing research results.

\section{REFERENCES}

Adorno, T. W., \& Horkheimer, M. (2006). The culture industry: Enlightenment as mass deception. In Durham, M. G. \& Kellner, D. M. Media and cultural studies keyworks, 41-72. Malden: Blackwell.

Akalili, A. (2018). Audience and public service advertisement about the dangers of smoking. Informasi, 48(2), 181-194.

Apter, D. E. (1996). Pengantar analisa politik.
Jakarta: LP3ES.

Asih, W. (2016). A semiotics analysis of the advertisements of bukalapak compare to tokopedia and elevenia. Semarang: Diponegoro University.

Atika, A. \& Chandrabuwono, A. B. (2018). Public service ads of reserving peat forest. Informasi, 48(2), 257-266.

AQUA. (2011). Tentang Aqua. Retrieved in April 6, 2018, from http://www.aqua. com/tentang_aqua.

AQUA. (2013). Kabar Aqua. Retrieved in April 6, 2018, from http://www.aqua. com/kabar_aqua/berita-perusahaan/ temukan-indonesiamu?ref=pencarian.

Barthes, R. (1964). Elements of Semiology. New York: HILL and WANG.

Basuki, A. (2017). Makna warna dalam desain. Surabaya: Politeknik Elektronika Negri Surabaya.

Cavallaro, D. (2004). Critical and cultural theory: Teori kritis dan teori budaya. Yogyakarta: Niagara.

Danesi, M. (2004). Message, signs, and meaning: A basic textbook in semiotics and communication theory. Canadian Scholars' Press.

Dewi, Y. L., \& Sugandi, M. S. (2019). Pengaruh iklan web series space \#"kenapa belum nikah?" terhadap brand awareness JD.ID. Profetik Jurnal Komunikasi, 12(1), 141-148.

Elisa, \& Firdaus, Y. (2015). Pengaruh iklan terhadap keputusan pembelian sabun lifebuoy. Jurnal Managemen dan Bisnis Sriwijaya, 13(3), 299-308.

Fauzi, A. (2018). Analisis wacana iklan pond's men \#lelaki masa kini versi Rio Dewanto. Capture: Jurnal Seni Media Rekam, 9(2), 15-27.

Fikri, K. (2018). Analisis pengaruh penggunaan teks di gambar iklan terhadap jangkauan dan interaksi konsumen. Profetik Jurnal Komunikasi, 


$$
11(2), 46-57 \text {. }
$$

Fiske, J. (1990). Cultural and communication studies. London: Routledge.

Hadadi, K., \& Almsafir, M. K. (2014). The impact of online advertising on proton sales among expatriates in Malaysia. Procedia: Social and Behavioral Sciences, 129, 274-281.

Jefkins, F. (1997). Periklanan. Jakarta: Erlangga.

Juliyanti, A., \& Zuhdi, S. (2012). Pengaruh iklan terhadap keputusan pembelian pada PT. Djojonegoro (studi kasus pada mahasiswa STIE Kesatuan Bogor). Bogor: Sekolah Tinggi Ilmu Ekonomi Kesatuan Indonesia Bogor.

Kasali, R. (1995). Manajemen periklanan: konsep dan aplikasinya di Indonesia. Jakarta: Pustaka Umum.

KBI. (2008). Kamus bahasa indonesia. Jakarta: Pusat Bahasa Departemen Pendidikan Nasional.

Kusumastutie, N. S., \& Faturochman. (2004). Analisis gender pada iklan televisi dengan metode semiotika. Jurnal Psikologi, 7(2), 130-141.

Lahitani, S. (2016). Aqua bantu ketersediaan air bersih di dua desa di NTB. Retrieved Juli 8, 2019, fromLiputan6:https://www. liputan6.com/citizen6/read/2624831/ aqua-bantu-ketersediaan-air-bersihdi-dua-desa-di-ntb.

Lukitaningsih, A. (2013). Iklan yang efektif sebagai strategi komunikasi pemasaran. Jurnal Ekonomi dan Kewirausahaan, 13(2), 116-129.

Morissan, M.A. (2010). Periklanan komunikasi pemasaran terpadu. Jakarta: Kencana Prenada Media Group.

Nisa, N. K. (2015). Strategi kreatif iklan layanan masyarakat (ILM) dalam pemasaran sosial. Interaksi: Jurnal Ilmu Komunikasi, 4(2), 158-164.

Nuradi, W.D. (1996). Kamus istilah periklanan. Jakarta: Gramedia Pustaka Utama.
Nurita, L. (2016). Pengaruh pesan iklan tokopedia versi "ciptakan peluangmu" terhadap minat berbisnis online. Serang: Universitas Sultan Ageng Tirtayasa.

Nursalim. (2014). Iklan dan implikasinya dalam pendidikan. Jurnal Penelitian Sosial Keagamaan, 17(2), 255-264.

Poluan, J. G., Lumintang, G. G., \& Untu, V. N. (2016). Pengaruh periklanan terhadap keputusan pembelian minuman coca cola (studi kasus pada PT. Bangun Wenang Beverage Company Manado). Jurnal EMBA, Jurnal Riset Ekonomi, Manajemen, Bisnis dan Akuntansi, 4(3), 671-681.

Prasasti, E. R. (2017). Analisis semiotika iklan Bukalapak edisi ibu kosan di televisi. Bandung: Universitas Pasundan.

Rahayu, N. U., \& Afrianto, D. T. (2017). Representasi citra laki-laki dalam iklan gatsby styling pomade kajian semiotika Roland Barthes. Capture: Jurnal Seni Media Rekam, 9(1), 93-107.

Safutra, I. (2019). JawaPos. Retrieved Juli 18, 2019, from Bantuan air tangki untuk warga Gunung Kidul yang kekeringan: https://www.jawapos.com/jpgtoday/20/o6/2019/bantuan-air-tangkiuntuk-warga-gunungkidul-yangkekeringan/.

Suryono, J., \& Astuti, P. I. (2013). Model media iklan potensial yang tepat sasaran produk unggulan UKM. Profetik Jurnal Komunikasi, 6(2), 17-26.

Suryono, J., Astuti, P. I., Rahayu, N. T., Widayati, M., \& Hariyanto. (2019). Karikatur iklan politik media luar ruang jangan membeli kucing dalam karung. Profetik Jurnal Komunikasi, 12(1), 46-6o.

Sobur, A. (2009). Semiotika komunikasi. Bandung: PT Remaja Rosdakarya.

Tinarbuko, S. (2009). Semiotika komunikasi visual. Yogyakarta: Jalasutra. 